\title{
RETRAINING OF THE DISCHARGED AND THE ONES LEAVING ACTIVE MILITARY SERVICE AS A TOOL FOR THEIR SOCIAL AND PROFESSIONAL MOBILITY
}

\author{
Venelin Terziev \\ Academician of the Russian Academy of Natural History, Moscow, Russia, \\ Prof. D.Sc. (Ec.), D.Sc. (National Security), D.Sc. (Social Activities), Ph.D., National Military \\ University, Veliko Tarnovo, Bulgaria; University of Rousse, Rousse, Bulgaria, terziev@skmat.com
}

\begin{abstract}
The dynamic changes in the social environment marked by positive and negative effects of the priority factors at the macro - and micro level and at the level of interpersonal relationships in the process of social adaptation of servicemen discharged from military service, determine the current importance of the need to search for suitable approaches to the formation of key competencies in them, based on which they can find their realization in the new living conditions.
\end{abstract}

Keywords: competence, social adaptation, servicemen, military service, education.

\section{INTRODUCTION}

The dynamic changes in the social environment marked by positive and negative effects of the priority factors at the macro - and micro level and at the level of interpersonal relationships in the process of social adaptation of servicemen discharged from military service, determine the current importance of the need to search for suitable approaches to the formation of key competencies in them, based on which they can find their realization in the new living conditions. Often facing too serious challenges, provoked by the change in the welfare status (professional, financial, value orientation, quality of life, etc.), the servicemen discharged from military service and the members of their families have two alternatives: slow evolutionary changes or dynamic, sharp revolutionary changes happening for a short time. Whatever alternative they choose, the adaptability to the civil socium itself implies the need for retraining, which is the basis of social and professional mobility of the military personnel discharged from military service.

\section{RETRAINING OF THE DISCHARGED AND THE ONES LEAVING ACTIVE MILITARY SERVICE AS A TOOL FOR THEIR SOCIAL AND PROFESSIONAL MOBILITY}

In solving the regarded problems, one must take into account all objective factors related to both the situation in the country and the emerging global situation. That means (on the basis of the ongoing reform of the army) setting a comprehensive plan for development (reconstruction) of the Armed Forces, which to 
develop a comprehensive military doctrine, to take into account the new realities in the country and the world, and only then to draw paths for achievement of the set objectives and tasks, including channels and mechanisms for socio-professional mobility of the military. Of course, the national policy on the management of the human resources in the Armed Forces should not deal primarily with the creation of social support systems for the servicemen discharged from service. On the one hand, this is assumed, as otherwise people are deprived of their primary professional status. But on the other hand, the very inclusion of the occupation type as a status to labour in general, as a generic status, implies socio-occupational mobility. Third, one can not but see what load the state takes when undertaking to provide protection for the educated workforce capable of working.

The root of the problem lies in the fact that the state is far from rational consideration of this aspect of its policy, which can be both expert and fully adequate and applicable.

The process of social and professional mobility is still active, though developing chaotically, and all its features are available: change of occupation, transition from one socio-professional layer to another. But the following circumstances are specific to the monitored process of mobility of the servicemen: massiveness, coercive and inadequate handling of the process, which is reflection of the inadequate national policy of the state in this regard. Here there is no timeliness when considering the social base for the reform and the real deadlines for its implementation.

The negative consequences of all this affect not only the families of the servicemen, but also the society as a whole and this affects the image of the army itself like a boomerang. The main problem is formed as the sharpest contradiction between the need to build a professional army and the practical discredit of the profession of the military as a result of the events bringing the military reform mainly to the reduction of its personnel.

Basically, these conflicts are not only related to the loss of permanent jobs. Naturally, people aspire to a profession which they can pursue for a lifetime. But there are also disappointments, and shift of professions that too often happens as a result of necessity. This conversion makes them face a lot of problems, the major one of which is finding a job, finding a home. In the absence of information in the conditions of the free labour market, there are many for whom the finding of a new job becomes a major problem. In this regard, of importance is the sociopsychological support, the core of which is training, retraining, improvement of skills and job placement. Moreover, in the today's increasing needs of the labour market for highly skilled professionals, education becomes a continuous process diverse in terms of the technology of its production process. Not surprisingly and quite naturally, in recent years there has been an establishment of a variety of educational structures that fill the gaps in our traditional educational system which is conservative in many ways (Banabakova, Georgiev, 2018; Banabakova, Georgiev, 2017; Glushkov, Simeonov, Georgiev, 2018a; Glushkov, Simeonov, 2018b-c).

For those discharged and leaving the ranks of the army, this issue is on the agenda for several reasons. Above all, often it is not about continuing education in the context of its continuity but about the change of the profession, although the basic education and the experience acquired over the years are essential. But we must not overlook the fact that their civil profession is "forgotten" or life already imposes new requirements on the professional competence in the profession acquired before.

The psychological factor plays a vital role, the shift of the profession accordingly reverses the fortune.

In this regard, the main mechanism should become a sound and actually functioning national military personnel policy, the core of which is the preparation and the placement of specialists for the time of their active service and after their discharge. The role of education should be considered with regard to the development of positive social and professional mobility.

The positive social self-esteem and job satisfaction are subjective indicators of the positive sociooccupational mobility of the discharged from active military service.

Another fundamental direction of the work is the development of legal mechanisms to guarantee the right of training of servicemen and the relevant conditions for living and working in the places of migration. Studies have shown that the training and the placement of servicemen are not expensive for the state. What is expensive is rather the so-called downward socio-occupational mobility, marked by a decline in the social status of servicemen discharged from military service in society. For the purpose of our study, we have therefore adjusted the methodology for sociological diagnosis of professional realization. The meaning of this methodology is limited to the establishment of orientation of the military to one or another type of professional development.

Since the main values acquired through work are professional - life self-fulfillment and life and social status 
(„expenses” and „salary”), the professional selfrealization of servicemen discharged from military service incorporates summarized parameters, such as professional achievements, needs and demands of professional knowledge and experience. Life and social status are described in the categories of professional development and career growth, social prestige of the professional activity and material wealth.

The key indicators outlining (in a comprehensive way) the vocational and the

life goal setting and motivation for work, which should be set in such a methodology are:

- Degree of creativity and initiative at work;

- Opportunity to apply one's professional knowledge and competence;

- Possibility of improvement of the professional experience;

- Satisfaction with the work performed;

- Feeling of the real benefit of the work performed;

- Autonomy in choosing the solutions to one's work tasks;

- Work in strict accordance with the characteristics of the position;

- Opportunity to teach others, to transfer their experience to others;

- Highly positive assessment of the results of the professional activity on

- The part of one's colleagues, the people around;

- Participation in developing strategies for the organization, development

- Of long-term plans;

- Realization of professional experience;

- leadership in the team;

- Oportunities for occupation of a higher position, for career development;

- High level of responsibility for the results of the professional activity;

- Higher salary;

- Prestigious position in society;

- Good chances for advancement at work;

- Prestige of the job;

- Additional financial incentives;

- Good relationship with the direct manager;

- Good relationships in the community;

- Rhythm of work without tension and stress;

- Better workplace (office, equipment).

The applicability of the adapted Methodology of macro diagnostics of the staff for the purpose of increasing the efficiency of the social adaptation of servicemen discharged from military service allows, based on the same set of indicators, to determine the structure of the self-assessment of the opportunities and the achievements in professional plan, of life-determining attitudes related to the professional activities.

The socio-ontological basis of this approach lies in the fact that through professional work, the serviceman reservists realize their personal and professional potential and the evaluation of the significance of their work ensures the appropriate material and social status in society for him. Of course, for this purpose, it is appropriate to have a set of indicators that reflect the complexity and the depth of the participation of the individual in the professional activity and the depth of the relevant personal experience.

The applicability of the Methodology of macro diagnostics requires comparing each of the given indicators with each one of the others in pairs. The total number of the pairs that are obtained with these 23 indicators is 253 and should be calculated according to the following correlation:

$\mathrm{n}=\mathrm{N}(\mathrm{N}-1) / 2=(22 \times 23) / 2=253$, where: $\mathrm{n}$ is the index; $\mathrm{N}$ - first indicator; $\mathrm{N}-1$ - second indicator 
The technology of the applicability of the methodology is the following: provision of a list to the beneficiaries, in the form of cards, each of which contains a pair of indicators; in the diagnosis of the attitudes, the general task of dealing with the cards should be formulated as follows: „in each pair of statements, select the most important for you at work, what you would be mostly aspired to"; place the card on the right or on the left, depending on whether the right or the left statement is the most important for the beneficent; introducing the cards, separated on the left, in questionnaires.

The processing of the obtained data is possible due to the applicability of the methods of factor and cluster analysis relevant for this purpose, as a result of which can be formed five typological groups of respondents, differing in their professional attitudes in the sphere of professional activity. The given typology is obtained in the space of two factors: the factor goalsetting related to the professional activity and the factor work motivation The content of these factors and their corresponding weights are shown in Tables 1 and 2.

Table 1. The factor professional and life goal setting.

\begin{tabular}{|c|c|c|}
\hline \multicolumn{2}{|r|}{ For the respondents it is important ... } & \multirow{2}{*}{$\begin{array}{l}\begin{array}{l}\text { Factor } \\
\text { weigh }\end{array} \\
0.642\end{array}$} \\
\hline 1 & ...to bear great responsibility for the results of their professional activity & \\
\hline 2 & ...to show creativity and initiative at work & 0.067 \\
\hline 3 & ...to see actual benefit from the work performed & 0.541 \\
\hline 4 & ...to teach others, to transmit their experience to others & 0.522 \\
\hline 5 & ...to be able to apply one's knowledge in practice & 0.506 \\
\hline 6 & ...to put into practice their professional experience & 0.454 \\
\hline 7 & ...to work in strict accordance with the instructions given & 0.425 \\
\hline 8 & ...to improve their professional experience & 0.425 \\
\hline 9 & ...to occupy a prestigious position in society & 0.768 \\
\hline 10 & ...to have good chances for growth at work & 0.740 \\
\hline 11 & ...to hold high office, to make a career & 0.695 \\
\hline 12 & ...to have a prestigious job & 0.691 \\
\hline 13 & ...to have a high salary & 0.643 \\
\hline 14 & ...to receive allowances & 0.474 \\
\hline
\end{tabular}

The high positive values of the factor goal setting, related to the labour activity (level 0.5 and higher), correspond to the expressed relations and attitudes towards the status of the servicemen reservists (professional), to the professional growth and the self-realization of the specialist. The low negative values for this factor (-0.5 or lower) reflect the attitude to the development of the professionalism of administrative type, to position growth and career and the corresponding social status. A factor value from -0.5 to 0.5 corresponds to a mixed, not strictly clear attitudes and relationships and therefore, this space is not characterized by typology (Petrova, Marinov, 2019; Petrova, 2019a; Petrova, 2010; Petrova, 2008; Atanasov, Mitev, 2016-a; Atanasov, Mitev, 2017b; Atanasov, Stoykov, 2016b).

Table 2. The motivation factor in professional activity

For the respondents it is important ... 
IJASOS- International E-Journal of Advances in Social Sciences, Vol. V, Issue 14, August 2019

\begin{tabular}{|c|l|c|}
\hline 1 & ...to form a strategy for the activity of the organization & 0.606 \\
\hline 2 & ..to hold high office, to make a career & 0.470 \\
\hline 3 & $\ldots$ to be leaders in the team & 0.443 \\
\hline 4 & $\ldots$ to be independent in solving production problems & 0.431 \\
\hline 5 & $\ldots$ to have good chances for growth at work & 0.367 \\
\hline 6 & $\ldots$ to have a rhythmic work without strain and stress & 0.734 \\
\hline 7 & $\ldots$ to have good relationships in the team & 0.571 \\
\hline 8 & $\ldots$ have a good work place & 0.553 \\
\hline 9 & ..to have a good relationship with the direct manager & 0.503 \\
\hline 10 & $\ldots$ to receive bonuses & 0.478 \\
\hline 11 & ..to perform their work in strict accordance with the requirements of the job & 0.471 \\
\hline
\end{tabular}

The high positive values of the factor labour motivation mean a high orientation to internal motivation, professional activity. They express the motivation for independence in choosing the solution to professional tasks, participation in developing a strategy for the organization, long-term plans for its development, leadership in the team, which corresponds to a creative attitude to work activity. The low negative values of this factor characterize the preponderant focus on external stimuli in the job, aiming at good working conditions, work without pressure and stress, performing the tasks in compliance with strict rules - executive type of attitude.

Thus, the applicability of the adapted methodology of macro diagnostics allows to assess the positive and the negative effects of the professional activity and the motivation of servicemen reservists according to the professional and social goal setting.

That is one aspect of the social and professional mobility of the military personnel discharged from military service. The other aspect is related to the place and the role of military education in this mobility.

Account should be taken of the fact that the problem of social protection of servicemen discharged from military service, their retraining and realization on the labour market is given considerable attention today. Parallel with this, one should not underestimate the fact that the reporting data of the NSI and EA show little progress in this direction.

Evidence about this is the great number of publications in scientific journals, collections, books, media. The problem of the social adaptation of servicemen discharged or leaving the ranks of the army is in the focus of scientific confrences, including international, numerous decisions and recommendations from these conferences. The more significant of these are:

- The army was and remains not only defender which has a place in the state system, but also its hostage. We can see how the socio-political changes in the country involve the army and the modern world is very dynamic in this respect;

- The transition to a professional army makes the military service rather a profession than a service, hence the resulting law inevitably accelerates the socio-professional mobility of staff in the field of the social division of labour. With its inclusion in the list of regulated professions, military profession became an equal element in the professional structure of society. Therefore, training of military personnel should become an element of the social technology of continuing education. This technology should provide opportunities for professional mobility of the military personnel in both its vertical and horizontal aspects.

In the broadest sense of the word, social technologies are certain components of the culture of humans that arise evolutionally, in the course of the historical process, as a mechanism to meet the specific historical needs. Arising spontaneously, social technologies can be built by the laws of culture as an artificial 
education, the main function of which is to achieve specific social goals.

In this context, profession is also a socio-technological mechanism that was established and developed within the social division of labour. Today, this socialtechnological mechanism is a unity of scientific, educational and practical-action processes, i.e. a complex social system. That determines the acceleration of the professional and the related social mobility of staff.

Note should be taken that profession "conquers people" through the whole complex of socio-cultural phenomena. In this, the most technological and mobile one is education: it can accumulate in itself the most valuable components of culture (including professional experience), using the tools of pedagogy to transform them for the purposes of adaptation to real cognitive and professional needs, to the abilities of students, consistently to organize the process of active life and creative activity of man, to initiate and stimulate selfacquisition of new knowledge. Moreover, it comes to education, as the sole, essentially enough sustainable technological sphere of formation of the human personality, which not only adapts to the specific external area, but can transform it through the professional activity.

On the basis of everything said, the reform of the army as a professional institution implies a reform of the relevant professional education, with a view to the new professional and educational realities. The main task in this direction is the creation of a system of continuing education in the field of military activity which would include preprofessional training, vocational education and further postprofessional education, which is related to the preparation and the retraining of the discharged from active service military personnel, ensuring their inclusion in various spheres of civilian professional activity.

The preprofessional military training as a component of the continuing military education refers primarily to military training in schools, vocational schools, colleges, high schools and universities. One should not take into consideration the fact that until recently initial military training has not been offered in school and university education. Thus, the system of preprofessional military education has already been destroyed and young people are unprepared in this direction - they do not even have access to such information. Moreover, in pursuit of secondary and higher education to form knowledge about the most important spheres of public life (economic, social, legal, basics of safety of health and labour), etc., the military domain as a sphere of the life and the work of the modern socium is excluded from the list. Only in recent years attempts have been made to restore military training as a component of secondary and higher education and the return of the military sphere in the today's society.

In any case the problem of establishing a system of continuing military education does not apply to the task of militarization of education. It refers to solving the problem of its social inclusiveness. This is extremely important in the context of the problems associated with building a small, mobile, high-technology professional army equipped with modern systems and armament, with clear priorities and defence capabilities adequate to the dynamic changes of the security environment and the growing resource deficit.

Vocational education continues to be a basic component in the system of the continuing military education. In the course of the reform of the army, this system is also subject to a change, but in all cases they are sufficiently effective and efficient, but at the cost of the discharge of thousands of servicemen with competencies and skills, in search of their way to the civil socium.

Although the military education system is built upon the integration of military and civic education, the changes in the social environment determine the problem of updating the curricula of both domains of continuing education in accordance with the changes and the requirements of the labour market. Solving this problem is achieved through the participation of universities, including the military ones, in various subgrants of the European Union under the Operational Program "Human Resources Development” for introducing new technologies for learning, improving the management system of higher schools for training and career development of the academic composition, updating the curricula in accordance with the labour market, etc. Thus it becomes possible to provide a reliable basis for the involvement of servicemen discharged from military service into civilian occupations with varying depth of conversion of the former military personnel (Terziev, 2019b-h).

Postprofessional education should also be with such an orientation. It is one of the most important units in the system of continuing military education and a mechanism for social protection of servicemen. Postprofessional education system is a link in the social and professional mobility of the military in the phase of their transition from the sphere of military activities to the civilian sphere. For that reason, its activities can not begin with the set of the already discharged specialists (Ivanov, 2014-a).

The existing educational and training centers need to have information on the labour market in the relevant areas so that they can promptly predict its dynamics and accordingly plan their activities. Thus, one of the 
most important mechanisms for shaping the system of continuing military education is its diversification, consistent with the educational standards. With regard to the large-scale diversification of the education system, the latter have the task to provide a single, common educational space, thus protecting students from the educational arbitrariness of individual institutions. This is the focus of the activity of the institution of the National Agency for Accreditation and Evaluation, as well as the accreditation of new specialties which are demanded, attractive and adequate to the social conditions in the field of security and defence, technical, economic, computer, social and other sciences, serving various spheres of the public life. Increasingly popular and relevant are the new accredited specialties associated with the management of security and defence, protection of the population from disasters, accidents and catastrophes, protection of critical infrastructure, logistics, computer systems and technologies, administrative security, communication and information systems, etc. Namely the knowledge, skills, abilities of servicemen in these areas should be used effectively in the period after their military service and during the transition to the civilian socium (Petrov, 2015; Petrov, Zagorov, 2016c; Petrov, 2017b-c; Petrov, 2018d-e).

\section{CONCLUSION}

Regarding the integration of military and civilian education according to the new social conditions, it is necessary to further plan the career of servicemen, in compliance with their educational and professional orientation. It is necessary to form a system of continuous military education, starting from the early stages and ending with the postprofessional education of the personnel and the servicemen leaving the ranks of the army. This is the basis for building a system for management of the human resources for security and defence, based on the management of competence and competences as one of the „big ideas ... together with the management by objectives and the total quality management ... and has become a key human resources strategy". Competency management is a complex of knowledge, skills and behavior corresponding to the security environment and the changes in the social environment, through which a final result is achieved. This means "the introduction of key competencies, which means" specifying the content and the objectives of the educational process", with an establishment of a "motivational, ethical, social and behavioral type" of personnel.

Through the competence approach it becomes possible to provide the competitive advantage of the capabilities of servicemen discharged from military service. The requirements of this approach are: the acquired knowledge as a result of the education of the individuals; the habits formed as a result of their professional experience and training; the way of communication resulting from the ability to communicate and work in a team. In itself this means lifelong learning, consistent with the European Union Programme "Lifelong Learning" 2007-2014 and the National Strategy „Lifelong Learning” 2014 (Terziev, 2019b-h).

\section{REFERENCE LIST}

Banabakova, V., Georgiev, M. (2018). Military professional forming of the cadets at Vasil Levski National Military University. // Proceedings of INTCESS2018- 5th International Conference on Education and Social Sciences 5-7 February 2018- Istanbul, Turkey, International Organization Center of Academic Research, www.ocerints.org, Istanbul, Turkey, 2018, pp. 462-467, ISBN: 978-605-82433-2-3.

Banabakova, V., Georgiev, M. (2017). Problems and perspectives in Military pro-fessional education and realization of cadets in Bulgaria. // Journal of Innovations and Sus-tainability, Innovations and Sustainability Academy. 3, 2017, N 4, pp. 37-47, ISSN 2367-8127 (CD-ROM), ISSN 2367-8151 (online).

Glushkov, P., Simeonov, S., Georgiev, M. (2018a). Method of determination of the diurnal energy consumption of the cadets from the Vasil Levski National Military university. // ADVED 2018- 4th International Conference on Advances in Education and Social Sciences Abstracts \& Proceedings, 1517 October 2018- Istanbul, Turkey, International Organization Center of Academic Research, www.ocerints.org, Istanbul, Turkey, 2018, pp. 88-92, ISBN: 978-605-82433-4-7.

Glushkov, P., Simeonov, S. (2018b). Study of the daily energy requirement of the cadets from Vasil Levski National Military University. // ADVED 2018- 4th International Conference on Advances in Education and Social Sciences Abstracts \& Proceedings, 15-17 October 2018- Istanbul, Turkey, International Organization Center of Academic Research, www.ocerints.org, Istanbul, Turkey, 2018, pp. 67-76, ISBN: 978-605-82433-4-7. 
IJASOS- International E-Journal of Advances in Social Sciences, Vol. V, Issue 14, August 2019

Glushkov, P., Simeonov, S. (2018c). Historical analysis of the daily energy requirements of the cadets in the Republic of Bulgaria. // ADVED 2018- 4th International Conference on Advances in Education and Social Sciences Abstracts \& Proceedings, 15-17 October 2018- Istanbul, Turkey, International Organization Center of Academic Research, www.ocerints.org, Istanbul, Turkey, 2018, pp. 77-87, ISBN: 978-605-82433-4-7.

Petrova, T., Marinov, M. (2019). Metodi i algoritmi za obrabotka na aerofoto i radiolokatsionni izobrazheniya, ulesnyavashti analiza na informatsiyata, Vtoro, preraboteno i dopalneno izdanie, Dolna Mitropoliya, 2019 g., ISBN 978-954-713-116-3, 246 str. (Петрова, Т., Маринов, М. Методи и алгоритми за обработка на аерофото и радиолокационни изображения, улесняващи анализа на информацията, Второ, преработено и допълнено издание, Долна Митрополия, 2019 г., ISBN 978-954-713-116-3, 246 стр.).

Petrova, Teodora, (2019a). Izsledvane i sintez na algoritmi za obrabotka na radiolokatsionni i optichni izobrazheniya s povisheno kachestvo, Dolna Mitropoliya, 2019 g., ISBN 978-954-713-117-0, 159 str. (Петрова, Теодора, Изследване и синтез на алгоритми за обработка на радиолокационни и оптични изображения с повишено качество, Долна Митрополия, 2019 г., ISBN 978-954-713-1170,159 стр.)

Petrova, Teodora, (2010). Izpolzvane na programata MULTISIM za poluchavane volt-amperna harakteristika na diod, Sbornik dokladi ot Nauchna konferentsiya "Nastoyashte i badeshte na aviatsionnoto obrazovanie v balkansko-chernomorskiya region na Evropa”, Dolna Mitropoliya 2010 g., str. 133-135, ISBN 978-954-713-094-4 (Петрова, Теодора, Използване на програмата MULTISIM за получаване волт-амперна характеристика на диод, Сборник доклади от Научна конференция „Настояще и бъдеще на авиационното образование в балканско-черноморския регион на Европа", Долна Митрополия 2010 г., стр. 133-135, ISBN 978-954-713-094-4).

Petrova, Teodora (2008). Savmestna lineyna obrabotka na izobrazheniya pri monitoring na okolnata sreda, Sbornik dokladi na Yubileyna nauchna sesiya "100 godini ot obyavyavane nezavisimostta na Balgariya", Dolna Mitropoliya 2008, str. 421-427, ISBN 978-954-713-092-0 (Петрова, Теодора, Съвместна линейна обработка на изображения при мониторинг на околната среда, Сборник доклади на Юбилейна научна сесия „100 години от обявяване независимостта на България”, Долна Митрополия 2008, стр. 421-427, ISBN 978-954-713-092-0).

Atanasov, M., Mitev, S. (2016). Tochnost na navigatsionnite kompleksi pri stranichno eshelonirane, Sbornik s nauchni dokladi ot parva nauchna konferentsiya s mezhdunarodno uchastie „Edinno evropeysko vazdushno prostranstvo - sashtnost i predizvikatelstvo pred vazdushniya suverenitet i biznesa" gr. Sofiya, VA „G. S. Rakovski”, 11 - 12 oktomvri 2016 g, str.90 - 96, Fondatsiya „Balgarski krile” Grup 2000VA” OOD ISBN 978-954-752-175-9 (Атанасов, М., Митев, С. Точност на навигационните комплекси при странично ешелониране, Сборник с научни доклади от първа научна конференция с международно участие „Единно европейско въздушно пространство - същност и предизвикателство пред въздушния суверенитет и бизнеса” гр. София, ВА „Г. С. Раковски”, 11 12 октомври 2016 г, стр.90 - 96, Фондация „Български криле” и „Еър Груп 2000ВА” ООД ISBN 978-954-752-175-9).

Atanasov, M., Mitev, S. (2016a). Tochnost na navigatsionnite kompleksi pri nadlazhno eshelonirane, Sbornik $s$ nauchni dokladi ot parva nauchna konferentsiya s mezhdunarodno uchastie „Edinno evropeysko vazdushno prostranstvo - sashtnost i predizvikatelstvo pred vazdushniya suverenitet i biznesa" gr. Sofiya, VA „G. S. Rakovski”, 11-12 oktomvri 2016 g, str.97 - 110, Fondatsiya „Balgarski krile” $i$ „Ear Grup 2000VA" OOD, ISBN 978-954-752-175-9 (Атанасов, М., Митев, С. Точност на навигационните комплекси при надлъжно ешелониране, Сборник с научни доклади от първа научна конференция с международно участие „Единно европейско въздушно пространство същност и предизвикателство пред въздушния суверенитет и бизнеса" гр. София, ВА „Г. С. Раковски”, 11-12 октомври 2016 г, стр.97 - 110, Фондация „Български криле” и „Еър Груп 2000ВА" ООД, ISBN 978-954-752-175-9).

Atanasov, M., Mitev, S. (2017a). Opredelyane na rabotnata oblast na dve dalekomerni radionavigatsionni ustroystva, Sb. ot dokladi na NK $2017 \mathrm{~g}$ - „Savremenni tendentsii v aviatsionnoto obuchenie“, fakultet „Aviatsionen“ kam NVU, D. Mitropoliya, 18-19.05.2017g., str. 100-107, ISBN 978-954-713-110-1 (Атанасов, М., Митев, С. Определяне на работната област на две далекомерни радионавигационни устройства, Сб. от доклади на НК 2017 г - „Съвременни тенденции в авиационното обучение“, факултет „Авиационен“ към НВУ, Д. Митрополия, 18-19.05.2017г., стр. 100-107, ISBN 978-954-713-110-1). 
Atanasov, M., Stoykov, O. (2016b). Tochnost na bombopuskane na metodite indikatsiya tochkata na padane, indikatsiya momenta na puskane i unifitsiraniya metod, $100 \mathrm{~g}$. ot rozhdenieto na k-n Dimitar Spisarevski, fakultet "Aviatsionen", D.M., 2016, s. 46-53,ISBN 978-954-713-109-5 (Atanasov, M., Stoykov, О. Точност на бомбопускане на методите индикация точката на падане, индикация момента на пускане и унифицирания метод, 100 г. от рождението на к-н Димитър Списаревски, фракултет “Авиационен”, Д.М., 2016, с. 46-53,ISBN 978-954-713-109-5).

Ivanov, Milen. (2014). Nasoki za povishavane nivoto na voenna podgotovka na kursantite, Sbornik dokladi ot godishna universitetska nauchna konferentsiya na NVU „V. Levski“, tom 3, V. Tarnovo, 2014 g., ISSN 1314-1937, str. 38-44 (Иванов, Милен. Насоки за повишаване нивото на военна подготовка на курсантите, Сборник доклади от годишна университетска научна конференция на НВУ „В. Левски“, том 3, В. Търново, 2014 г., ISSN 1314-1937, стр. 38-44).

Ivanov, Milen. (2014a). Formirane na informatsionno-obrazovatelna sreda za voenna podgotovka, Sbornik dokladi ot godishna universitetska nauchna konferentsiya na NVU „V. Levski“, tom 3, V. Tarnovo, 2014 g., ISSN 1314-1937, str. 45-52 (Иванов, Милен. Формиране на информационнообразователна среда за военна подготовка, Сборник доклади от годишна университетска научна конфреренция на НВУ „В. Левски“, том 3, В. Търново, 2014 г., ISSN 1314-1937, стр. 45$52)$.

Terziev, Venelin. (2019b). The dependence social adaptation- socialization. // INTCESS 2019- 6th International Conference on Education and Social Sciences, 4-6 February, 2019, Dubai, International Organization Center of Academic Research, Istanbul, Turkey, pp. 478-485, ISBN: 978-605-82433-5-4.

Terziev, Venelin. (2019c). Social adaptation of military servicemen, discharged from military service, in dynamic social environment. // INTCESS 2019- 6th International Conference on Education and Social Sciences, 4-6 February, 2019, Dubai, International Organization Center of Academic Research, Istanbul, Turkey, pp. 486-493, ISBN: 978-605-82433-5-4.

Terziev, Venelin. (2019d). Conceptual framework of social adaptation. // INTCESS 2019- 6th International Conference on Education and Social Sciences, 4-6 February, 2019, Dubai, International Organization Center of Academic Research, Istanbul, Turkey, pp. 494-503, ISBN: 978-605-82433-5-4.

Terziev, Venelin. (2019e). Model for social-psychological assistance for servicemen, discharged from military service. // INTCESS 2019- 6th International Conference on Education and Social Sciences, 4-6 February, 2019, Dubai, International Organization Center of Academic Research, Istanbul, Turkey, pp. 504-513, ISBN: 978-605-82433-5-4.

Terziev, Venelin. (2019f). Social adaptation as an element of social policy. // INTCESS 2019- 6th International Conference on Education and Social Sciences, 4-6 February, 2019, Dubai, International Organization Center of Academic Research, Istanbul, Turkey, pp. 514-521, ISBN: 978-605-82433-5-4.

Terziev, Venelin. (2019g). Analysis of the Bulgarian experience in the development of the social adaptation of servicemen, discharged from military service. // INTCESS 2019- 6th International Conference on Education and Social Sciences, 4-6 February, 2019, Dubai, International Organization Center of Academic Research, Istanbul, Turkey, pp. 522-534, ISBN: 978-605-82433-5-4.

Terziev, Venelin. (2019h). Complex model of social adaptation of servicemen, discharged from military service. // INTCESS 2019- 6th International Conference on Education and Social Sciences, 4-6 February, 2019, Dubai, International Organization Center of Academic Research, Istanbul, Turkey, pp. 535-545, ISBN: 978-605-82433-5-4.

Petrov, N. (2015). Sashtnost i struktura na protsesa na voenno obuchenie na kursantite ot NVU „Vasil Levski“ obuchavashti se po uchebnite planove ot 2012 godina., Sbornik dokladi ot godishna universitetska nauchna konferentsiya, 16-17 Yuli 2015g., Tom 10, Izdatelski. kompleks NVU, „Vasil Levski" V. Tarnovo, str. 187-194, ISSN 1314-1937 (Петров, Н. Същност и структура на процеса на военно обучение на курсантите от НВУ „Васил Левски“ обучаващи се по учебните планове от 2012 година., Сборник доклади от годишна университетска научна конференция, 16-17 Юли 2015г., Том 10, Издателски. комплекс НВУ, „Васил Левски” В. Търново, стр. 187-194, ISSN 13141937).

Petrov, N., Zagorov, N. (2016c). Sashtnost na voennoprofesionalnata podgotovka, pridobivana ot kursantite v NVU „Vasil Levski“ i rolyata ѝ za formirane na profesionalni kompetentsii, Sbornik dokladi ot godishna universitetska nauchna konferentsiya, 20-21 Oktomvri $2016 \mathrm{~g}$., Tom 4, Izdatelski. kompleks NVU, „Vasil Levski” V. Tarnovo, str.225-230, ISSN 1314-1937 (Петров, Н., Загоров, Н. Същност на 
военнопрофресионалната подготовка, придобивана от курсантите в НВУ „Васил Левски“ и ролята иे за фрормиране на професионални компетенции., Сборник доклади от годишна университетска научна конференция, 20-21 Октомври 2016г., Том 4, Издателски. комплекс НВУ, „Васил Левски” В. Търново, стр.225-230, ISSN 1314-1937).

Petrov, N. (2017b). Izsledvane stepenta na udovletvorenost na komandirite na formirovaniya za komunikatsionno-informatsionna poddrazhka ot nivoto na izgradenite profesionalni kompetentsii v ofitserite, zavarshili spetsializatsiya „Voenni komunikatsionni i informatsionni sistemi“., Sbornik dokladi ot mezhdunarodna nauchna konferentsiya, Shumen, 2017, str. 444-452, ISSN 2367-7902 (Петров, Н. Изследване степента на удовлетвореност на командирите на формирования за комуникационно-информационна поддръжка от нивото на изградените професионални компетенции в офицерите, завършили специализация „Военни комуникационни и информационни системи“., Сборник доклади от международна научна конференция, Шумен, 2017, стр. 444-452, ISSN 2367-7902).

Petrov, N. (2017c). Otsenyavane kachestvoto na obuchenie chrez izsledvane udovletvorenostta na potrebitelite na kadri. Sashtnost na potrebitelskata udovletvorenost i metodi za opredelyaneto ì., Sbornik dokladi ot godishna universitetska nauchna konferentsiya, 1-2 Yuni 2017g., Tom 3, Izdatelski kompleks NVU „Vasil Levski”, V. Tarnovo, str.77-85, ISSN 1314-1937 (Петров, Н. Оценяване качеството на обучение чрез изследване удовлетвореността на потребителите на кадри. Същност на потребителската удовлетвореност и методи за определянето й., Сборник доклади от годишна университетска научна конференция, 1-2 Юни 2017г., Том 3, Издателски комплекс НВУ „Васил Левски”, В. Търново, стр.77-85, ISSN 1314-1937).

Petrov, N. (2018d). Methopdology for asseing the quality of conducted training., Journal of Innovations and Sustainability, Vol. 4, No 3, 2018, p 27-37, ISSN 2367-8127 (CD-ROM), ISSN 2367-8151 (on-line).

Petrov, N. (2018e). Sashtnost na profesionalnite kompetentsii, KNOWLEDGE - International Journal, September 2018, Vol. 26.3, Institute of Knowledge Management, p.869-874, ISSN 2545-4438, (online) ISSN 1857-923X (Петров, Н. Същност на професионалните компетенции., KNOWLEDGE International Journal, September 2018, Vol. 26.3, Institute of Knowledge Management, p.869-874, ISSN 2545-4438, (on-line) ISSN 1857-923X). 